\title{
Highlights of the 2006 AAN Meeting Activities for Trainees
}

\section{$5^{\text {th }}$ Annual AAN Meeting Information}

April 1-8 2006

San Diego, California

Full program information is available at http://am.aan.com

Next year's meeting: April 28-May 5, 2007, Boston, Massachusetts

\section{Free Events for Registered Residents/Fellows}

1. Scientific Platform Sessions

2. Poster Sessions

3. Plenary Sessions

4. Education Colloquium

5. Patient Safety Colloquium

6. Exhibits

7. Scientific and Career Milestones Award Luncheon

8. Neurobowl and Opening Party

9. Consortium of Neurology Residents and Fellows

10. SIGN Meeting

\section{Selected Sessions of Special Interest to Trainees}

1. ABPN informational session

2. Medical Student Resident Rush Line

3. Consortium of Neurology Residents and Fellows

4. Resident Fellowship Panel/Poster Forum and Reception

Please see http://am.aan.com for full details 


\section{Neurology}

\section{Highlights of the 2006 AAN Meeting Activities for Trainees \\ Neurology 2006;66;E8 \\ DOI 10.1212/WNL.66.1.E8}

This information is current as of January 9, 2006

Updated Information \&

Services

Permissions \& Licensing

Reprints including high resolution figures, can be found at: http://n.neurology.org/content/66/1/E8.full

Information about reproducing this article in parts (figures,tables) or in its entirety can be found online at:

http://www.neurology.org/about/about_the_journal\#permissions

Information about ordering reprints can be found online:

http://n.neurology.org/subscribers/advertise

Neurology ${ }^{\circledR}$ is the official journal of the American Academy of Neurology. Published continuously since 1951, it is now a weekly with 48 issues per year. Copyright . All rights reserved. Print ISSN: 0028-3878. Online ISSN: 1526-632X.

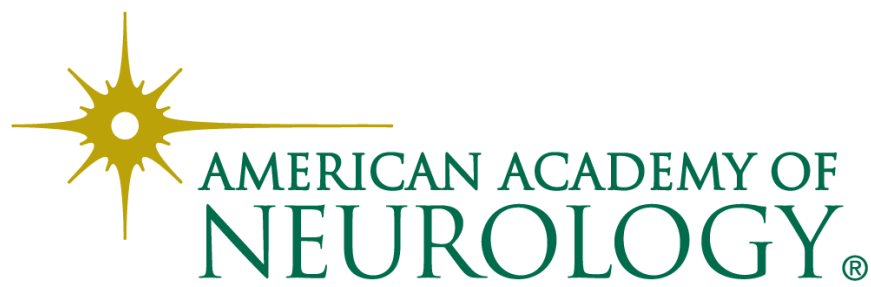

